\title{
FAR EASTERN PROMISES: THE FAILED EXPEDITION OF THE HUDSON'S BAY COMPANY IN KAMCHATKA AND EASTERN SIBERIA (1919-1925)*
}

\author{
Robrecht Declercq \\ Research Foundation Flanders (FWO), \\ Ghent University, \\ Ghent, Belgium
}

This article is devoted to the attempt of the Hudson's Bay Company (HBC) to create a new fur trading empire in Eastern Siberia and Kamchatka during and after the Civil War (1919-1925). It was one of the most controversial and substantial attempts by a foreign company to do business in Soviet Russia, and therefore is a unique case study for understanding the relationship between the young USSR and foreign business. The Kamchatka expedition is often understood as a case of the HBC's naïve and poor judgment of the political risks involved. However, this article argues for a broader understanding of the expedition, one that takes into account specific business strategies, geo-economic Arctic developments, and the historical conditions in which trade in the area had unfolded in the decades leading up to the First World War. Concerning the last point, American traders based in Nome and Alaska had successfully traded in the Kamchatka area and set up a system in which they provided supplies to native and Russian communities in the Far East in return for furs (either by barter or for legal tender). Importantly, the system made inhabitants of the area dependent upon these supplies. The HBC's endeavor in Kamchatka was an attempt to take over and continue these lucrative operations, but it also suited its expansionist business strategy elsewhere. From the early twentieth century, the $\mathrm{HBC}$ had been setting up new trade posts in the Canadian Arctic in a response to suffocating competition in mainland Canada. As such, the Kamchatka operation seemed like a logical extension of this expansionist strategy. In addition, doing business in the high north led private business to form specific expectations: state presence in the area was feeble, regardless of its political allegiance. The article, then, explores the fortunes of the company in Siberia. It shows that the company easily adapted to local conditions by successfully contracting local middlemen. It also shows that the difficulties of operating in the area were not only caused by underestimation of the political risks, but also because the company suffered from enormous logistical problems:

* Citation: Declercq, R. (2019). Far Eastern Promises: The Failed Expedition of the Hudson's Bay Company in Kamchatka and Eastern Siberia (1919-1925). In Quaestio Rossica. Vol. 7, № 2. P. 571-586. DOI 10.15826/qr.2019.2.394.

Цитирование: Declercq R. Far Eastern Promises : The Failed Expedition of the Hudson's Bay Company in Kamchatka and Eastern Siberia (1919-1925) // Quaestio Rossica. Vol. 7. 2019. № 2. P. 571-586. DOI 10.15826/qr.2019.2.394.

(C) Declercq R., 2019

Quaestio Rossica • Vol. 7 • 2019 • № 2, p. 571-586 
it also had trouble adapting to the environmental circumstances, despite its experience in remote territories. The eventual restoration of territorial integrity initially brought about cooperation between the USSR and the HBC, illustrating that the USSR was aware of the pressing need to supply the area, even though such a policy was at odds with the state monopoly on trade. The cooperation ended with the withdrawal of the HBC, as it considered trade conditions too unpredictable.

Keywords: Russian civil war; fur trade; Kamchatka; trade monopoly; Soviet foreign trade; Arctic; business and war.

Статья посвящена попытке Компании Гудзонова залива (КГЗ) создать новую империю по торговле пушниной в Восточной Сибири и на Камчатке во время и после Гражданской войны (1919-1925). Это была одна из самых серьезных и противоречивых попыток иностранных компаний вести дела в советской России, и, в связи с этим, она представляет большой интерес, так как проливает свет на отношения молодого советского государства и иностранных предпринимателей. Камчатская экспедиция часто трактуется как пример наивного и неглубокого представления КГЗ о возможных политических рисках. Однако автор статьи настаивает на более широком взгляде на экспедицию с учетом специфики ведения дел, геоэкономических особенностей Арктики и исторических событий, в которых развивалась торговля в регионе в десятилетия, предшествующие Первой мировой войне. Американские торговцы из Нома и Аляски успешно вели дела на Камчатке. Им удалось создать систему, благодаря которой они обменивали товары, необходимые коренному и русскому населению Дальнего Востока, на меха (по принципу бартера или за валюту). Важно отметить, что эта система сделала местных жителей зависимыми от иностранных поставок. КГЗ хотела перенять этот опыт на Камчатке, так как подобное взаимодействие представлялось чрезвычайно выгодным, и, кроме прочего, вписывалось в стратегии экспансии компании. С наступлением XX в. КГЗ начала создавать новые торговые посты на канадских арктических территориях в качестве альтернативы таковым в континентальной Канаде, где конкуренция была слишком высока. Торговое освоение Камчатки в этой связи выглядело логичным в рамках дальнейшей экспансии компании. Кроме того, ведение дел на Дальнем Севере привело к формированию у частных предпринимателей особых ожиданий, связанных с этой территорией: государственное присутствие там было минимальным, несмотря на политическую лояльность региона власти. Настоящая статья посвящена деятельности компании в Сибири. Показано, что КГЗ легко адаптировалась в регионе, наняв местных посредников, а сложности ведения дел там были связаны не только с недооцениванием политических рисков, но также с тем, что компания испытывала серьезные логистические проблемы в суровом дальневосточном климате, несмотря на имеющийся опыт торговли на Севере. Восстановление территориальной целостности первоначально привело к сотрудничеству СССР и КГЗ, что свидетельствовало о по- 
нимании СССР необходимости обеспечения региона товарами, однако такая политика шла вразрез с государственной монополией на торговлю. Сотрудничество закончилось уходом КГЗ из СССР, так как компания считала условия торговли непредсказуемыми.

Ключевые слова: Гражданская война в России; торговля пушниной; Камчатка; торговая монополия; международная торговля СССР; Арктика; предпринимательство и война.

War has vast consequences for international business. It seals off foreign markets and supplies, but can also sometimes provide unexpected opportunities. This was particularly the case of the First World War and Russia. By the end of the nineteenth century, Russia had become one of the most attractive outlets for international businesses. Between 1880 and 1913, over $50 \%$ of all capital invested in industrial corporations was of foreign origin [Dunning, Lundan, p. 172]. French, German and Belgian businesses gained a strong foothold, and many trading businesses organised the export of Russian raw materials abroad. The war drastically changed the conditions for international business in Russia. First, German businesses lost their assets, since such was considered to be property belonging to the citizens of an enemy state. In 1917, the Bolshevik Revolution threatened the presence and activities of all foreign enterprises. Nonetheless, many businesses still considered the revolution and its chaotic aftermath to be an opportunity. This was especially the case in regions east of the Urals, outside Soviet control during the Civil War. Indeed, the Allied military occupation of the eastern area of Siberia was predicated upon the hope of re-establishing trade interests and obtaining concessions with regards to Siberia's mineral wealth. Such motives undergirded British business in particular: its ineffectiveness in establishing a strong trade interest in this part of the world before the war constituted a painful lacuna [DavenportHines, Jones, p. 80]. While these economic aspirations in post-revolutionary Russia would remain a pipe dream, several attempts to set up new business empires did take place. One of the most important, controversial and long-standing ventures was the Hudson's Bay Company's Kamchatka expedition, a fruitless but serious attempt to control the furs of Eastern Siberia and the Kamchatka Peninsula during the Civil War and after. The venture started in 1919 and ended in 1924, when the HBC, the largest fur trading company in the world, officially decided to withdraw. In this limited time, however, the company managed to set up a trading operation of considerable magnitude, based on supplying the area with foodstuffs and consumables in return for the fur wealth of Kamchatka. This article is devoted to this Kamchatka venture in an effort to better understand how international businesses functioned during the post-revolutionary war and their motivations for taking advantage of this chaos. Equally, I consider how the USSR finally came to manage business intrusion in those parts of the country that were remote and difficult to control. 
The historical literature on the HBC Kamchatka expedition in the 1920s remains limited and has somewhat indulged in the benefit of hindsight. Most explanations point, correctly, to the company's poor assessment of the very risky political situation [Dalton, 2006]. Bockstoce talks of the "optimistic" and even "naïve" assumption of the $\mathrm{HBC}$ that the territorial power of the Soviet Union would not extend to the remoter parts of the Asian coast and Kamchatka as the company's main rationale [Bockstoce, p. 126]. Such explanations are rather problematic, as they are prone to condemning, rather than explaining, the attempts of foreign companies to operate in the Soviet Union during the Civil War. In contrast, this article is built on the argument that the Kamchatka fiasco needs to be understood in terms wider than the political risks; it also has to be set against the canvas of shifts in the global fur trade in general and the HBC's renewed business strategies in particular.

Gradually losing its monopoly over the trade in mainland Canada throughout the $19^{\text {th }}$ century, one of the HBC's main efforts to maintain its leading position in the global fur trade was to seek new frontier territory in which it could establish trade activities. The HBC therefore turned to new frontier territories in the high north, such as the Canadian Arctic [Declercq]. The stage of expansion was both the Eastern Arctic (north of the Hudson Bay towards Baffin Island) and the Western Arctic (towards the Beaufort Sea) [Newman, p. 246]. As such, a reinvigorated wave of expansion based on fur trading took place during the early twentieth century. This expansion led to new connections, especially between Alaska and the Chukotski Peninsula, but there were also growing links between Siberia and Canada in the years leading to the war, based upon Russia's desire to populate Siberia and the economic development of Canada's territories on the Pacific. Such connections and visions of future trade relations were of fundamental importance, as Black has argued, to Canada's policy of intervention during the Civil War [Black, p. 26-27].

In stressing the economic foundation behind Canada's military intervention, it becomes clear that the interest of the HBC in Siberia was not an isolated case of shortsightedness; instead, it unfolded in a context in which other stakeholders saw the potential of transpacific trade and investments in post-revolutionary Russia, regardless of the conflict's political outcome. As such, the hypothesis of this paper is that the brief expedition in Kamchatka should be read on a longer and larger temporal and spatial canvas as part of a renewed wave of expansion in the fur trade that relied on growing economic interconnections between North America and the Russian Far East before the First World War. This is not to deny that the HBC did indeed painfully underestimate the political risks, but one should also stipulate that the Kamchatka venture was part and parcel of the HBC's aspirations to establish a new fur trade empire with a center of gravity closer to the recently explored Arctic areas of the globe. As part of this strategy, the company was willing to take risks and adopt longterm perspectives when developing new trade territory. These factors, it is hypothesized, blinded the HBC to the many obvious political risks involved. 


\section{Signaling opportunities (1916-1921)}

The HBC's interest in doing business in Russia's Far East began long before the October Revolution in 1917. The initial expression of interest in Siberia was strongly connected to the desire of the British authorities to strengthen their feeble presence in the area at the expense of the Germans. It was the Foreign Office that took an interest in the sequestration of German businesses during the war, especially the Kunst \& Albers trading house in Vladivostok. The Kunst and Albers merchant house, founded by two Hamburg traders in 1864, was a major stronghold of German commerce in the Russian Far East, being the market leader in wholesaling and retailing in the area. In the fur trade, however, the Vladivostok company played only a minor role. The commercial intelligence service of the Foreign Office stressed the similarity in organizational structure to the HBC: "the Kunst \& Albers concern resembles very closely in the Far East the trading operations of the Hudson's bay Company in Canada, possessing large distribution depots and retail stores at the chief centers of population in Eastern Siberia" [TNA. BH 1/2215. A 12FTMISC/250. F. 2-3].

The only reason the Russian government was attracted to the take-over was the ability of the $\mathrm{HBC}$ to continue trading operations, which illustrates the "extreme state of dependency of the Siberian population" on supplies shipped in from abroad [Murby, p. 73]. However, the HBC's logistics, fleet, and organizational structure were at that time strongly tied to the war effort (especially in terms of provisioning the Allies and organizing their supplies), meaning that it was unable to "attend to an extension of this magnitude in Russia” [TNA. BH 1/2215. A 12FTMISC/250. F. 4-5]. Even though the HBC refused to take over the Kunst \& Albers concern, its interest in Russia during the war expanded. It ran a shipping business in Arkhangel'sk from 1915 to 1919. In 1919, the HBC also participated in the Siberian Supply Company, which was designed to sell goods from the British government in Siberia [Black, p. 14].

The fur trade fitted the scheme of British and Canadian officials to expand their commercial presence in the area, as buying furs in remoter areas typically went along with delivering supplies, such as foodstuffs, ammunition and alcohol: "It struck me that if the Hudson's Bay Company could come in and start fur trading it would supply an additional means of exchange which would be very valuable. Firstly, the Company if it followed the usual lines, would no doubt get rid of a lot of goods by the direct process of barter of furs. Then, so far as it required money for local expenditure, it would supply an additional fund for the purchase of Canadian or British goods" [TNA. BH 1/3452. A.93/12. F. 12]. Still, the HBC remained remarkably hesitant to carry the burden of such an operation entirely on its own: "the organization of the fur trade in Canada is unique, and we do not know whether we will be fitted to engage in competition for a business which has developed upon such entirely different lines." [TNA. BH 1/2603. A5/129. F. 223]. Instead, the board chose a safer route to the fur wealth of the Far East. 
In 1919, the HBC entered a joint venture set up between a trader by the name of Count Berg and Sale \& Frazar, a British and American trading and engineering firm that operated in Japan [Shavit, p. 174]. The HBC became the main shareholder with $60 \%$ of the shares. The partnership was informally known as the Trio Account, but it was officially registered as the Kamchatka Fur Trade Company. At this stage, the HBC was not directly involved in local commercial activities, and trading goods were purchased principally from the warehouses of Sale \& Frazar in Tokyo. While it was difficult to establish new trade posts owing to distrust towards foreigners, the Kamchatka Fur Trade Company primarily operated with local Russian traders and staff scattered over 15 trading posts to secure furs.

It was already during the Trio Account that the trade partners, in particular Count Berg, asked for greater involvement from the HBC. For instance, shipments in 1920 were brought in by Japanese steamers, with representatives who knew too little of the fur trade [TNA. BH 1/2633. A 92/17/21. F. 26]. Count Berg asked whether a HBC ship could be deployed in the area, along with experts in grading and valuing Kamchatka furs. By this point, however, the HBC had already been seriously contemplating a larger, more direct role in the Siberian trade. The motivation for this was not simply exploiting the power vacuum. It was also taken from a specific business point of view that was tied to the historical development of the fur trade in North America in recent decades. When the HBC board contemplated in 1920 the difficult matter of how deeply the company should be involved in the Siberian trade, HBC traders stressed that the opening of a direct Siberian coastal trade constituted a logical extension of existing HBC operations in the Canadian Western Arctic. Provisions to these northern areas were primarily procured in Vancouver and Nome in Alaska. Much of the trade in the area had already organized in a transpacific fashion for decades, with American traders like Hibbard \& Swenson operating from Seattle since 1902, bartering and trading along the Siberian coast. In Nome, Alaska, local traders were similarly enthusiastic about accelerating the exploitation of the Alaskan and Siberian Arctic during the Civil War [Hunt, ch. 6].

With its Western Arctic operations expanding, the HBC could participate in this profitable trade and compete with the Alaskan-based traders. Norman Freakley, a HBC captain active in the Western Arctic, saw that HBC ships could easily serve both Herschel Island and parts of the Siberian coast. He therefore recommended a more direct approach and "to set up regular trade posts along the Siberian coast, similar to these existing on the Hudson Straits" [TNA. BH 1/2623. A 92/17/6. F. 78]. Freakley emphasized that fur trading operations could profit because of the chaos in the area: "owing to the unsettled state of the country", supplies were urgently needed [Ibid.]. In addition, the fortunes of competitors were evaluated, in particularly the loss of a schooner by Hibbart \& Swenson, a trading company with a strong presence in the area: this was seen as an extra opportunity that worked to the advantage of the HBC. 
Indeed, from such a geo-economic perspective, setting up trade activities in Siberia does seem more like a 'natural' extension of intensifying trade activities in the transpacific north rather than the exploitation of a windfall opportunity. Moreover, one should not underestimate the extent to which Arctic exploitation and exploration was the subject of wishful thinking at the time. Arctic space, remote, barely explored and sparsely inhabited, was very much seen by contemporaries as open and vacant land, the last blank space on Earth where formal sovereignty was often not carved in stone. This applied to the Russian Far East as well. For instance, the sovereignty of Wrangell Island in the Chuckchi Sea was disputed, as American expeditions tried to lay claim to it. In terms of the wider Chuckchi Peninsula, north of Anadyr, the HBC noted that the presence of American traders operating from Nome (Alaska) was much stronger than any formal Russian presence and that Russian authority in the region "was so slight" [TNA. BH 1/2634. A 92/17/25. F. 179-184]. In large parts of the area where the HBC wanted to trade, Russian authority was indeed insignificant, leaving much leeway to individual traders. As such, the HBC's entry into the fur trade in Siberia involved many other factors besides a simple misjudgment of the political risks. In large parts of the territory, government interference was largely absent, regardless of who was in power. The company highly favored such "free", frontier-like conditions: they also underlay the expansion into the Canadian Arctic, where state interference was virtually absent as well [Declercq].

\section{Setting up shop (1921-1923)}

At the beginning of 1921, the Kamchatka Fur Company was dissolved when Count Berg and Sale and Frazar withdrew. At this point, the HBC took the unfortunate decision to continue alone, however, at this moment such seemed like a logical continuation of its previous efforts. In organizing the trade on its own account, the HBC continued to service the basic system of trade posts used by the Trio Account. Amongst company administrators, there was mounting confidence that their investments were eventually going to pay off: a number of new settlements and posts were integrated into the system. By 1923, the company commanded a network of over 25 trade posts, extending from Port Ayan on the south-western coast of the Okhotsk Sea to Cape North in the Russian Arctic. This covered a coastline of over 3,500 miles, connected to inland transport routes (rivers, tracks) totaling over 700 miles [TNA. BH 1/2702. A 92/30/1. F. 161]. Trade posts were situated on both sides of the Kamchatka Peninsula, on the Sea of Okhotsk and a long stretch on the Bering Sea, opposite Alaska towards the Bering Strait. In Olyutorsky district, the port town of Anadyr figured as the headquarters of the HBC's operations. Even further north along the Chutchi Sea, a post was established at the Chukotsk River. Further south, significant posts were situated at the mouth of the Uka and Kamchatka rivers [TNA. BH 1/2628. A 92/8/1. F. 46]. The HBC's main site in the southern area was the port of Petropavolvsk, strategically situated almost at the southern end of the peninsula [Ibid. F. 44]. 
Next to the peninsula itself, the HBC called at ports on Eastern Siberia's coastline along the Sea of Okhotsk, like Chukotsk and Ayan.

The trade infrastructure varied considerably. Some settlements did have substantial warehouse infrastructure to safely store supplies and furs for sale. This was the case in Okhotsk, a proper town with government buildings, a wireless station and substantial log houses situated on the Siberian mainland. In other places, by now mostly abandoned, new infrastructure was created by the company itself. This was the case in the port of Ayan, where a new storage area was established. While Ayan was already remote and hard to service, some places, especially on the peninsula itself, lacked warehouse and port infrastructure. A telling example is Olyutorka, where the HBC's Russian representative Arteymnoff had made most of the material available and had created a store out of "dunnage, earth and corrugated iron" [TNA. BH 1/2628. A 92/8/1. F. 15].

The lack of knowledge about local markets previously holding the company back from direct operations in the area was solved in two ways. First of all, the HBC hired the Dutch trader Anton Hoogendijk to manage the Kamchatka expedition: he was given a large degree of autonomy. Hoogendijk, a Russian-speaking go-between based in Arkhangel'sk with whom the company had been in business during the war, established the majority of posts on the coast of Kamchatka that bordered the Bering Sea: ships could easily reach this area from the port in Vancouver. Secondly, while the trading posts in Canada were controlled by their own staff (so-called post managers), the HBC in the Russian Far East continued to outsource control over posts to local traders, just like under the Trio Account. One of the main trading partners was the Russian trade firm the Karieff Brothers, with an operating base in Anadyr. The Karieff brothers were granted extensive credit of \$150,000 in order to conduct the fur trade on behalf of the company [Ibid. F. 42].

Besides the Russian go-betweens, however, the way in which trade functioned resembled the way the $\mathrm{HBC}$ operated in Canada. Hunters and trappers, chiefly natives, brought the furs to $\mathrm{HBC}$ stores, from where these fur suppliers received provisions such as foodstuffs, weapons, ammunition and alcohol [Ray, p. 2]. The Russian middlemen assumed the function of "storekeepers", drawing in furs and distributing HBC supplies shipped in during the ice-free season across these vast regions [Ibid. F. 21]. This is how the fur trade historically worked on frontiers, especially in North America. The trading of furs for supplies was also the basis of the trade on the remote Kamchatka Peninsula established by American traders in the late $19^{\text {th }}$ century. It made local people, natives or settlers, dependent on the post for supplies and foreign suppliers [Yarzuktkina, p. 377]. This supply function was key to the trade in the remote parts of Kamchatka and Eastern Siberia, and made goods like furs a valuable exchange commodity to the traders who supplied the area. Marchenko, a Russian representative of the $\mathrm{HBC}$, noted that "the need of all kinds of goods by the people is great. They need everything, but have no means of buying 
the goods. If anyone has any fur he tries not to trade it for merchandise and usually is hiding all he has for fear he will be relieved of it" [Ibid. F. 35]. As such, the need for supplies in exchange for furs formed the basis of trading in this era.

\section{Command of the seasons: force majeure and political instability}

While the operation made general sense in terms of the customary principles of fur trading, and those of the HBC in particular, in practice the HBC was confronted with numerous complications. To service the remote Russian posts and to bring the furs back, the HBC deployed one of its most important vessels, the Baychimo, in the Kamchatka area. In addition, a number of smaller trade vessels, mostly from Japan, were chartered to call at other trade posts. Nature, however, did not cooperate: it became clear that the scale which the HBC intended for its Siberian business was far too ambitious. In 1922, Anton Hoogendijk painted a negative picture of the Kamchatka expedition in his report to the company's governor and committee. Particularly harsh conditions during the summer had troubled supply ships. The summer ice melted relatively late and had coincided with hostile weather conditions such as heavy gales and fog, which made it impossible to provide all trade stations with the necessary provisions and caused considerable delay. These were harshest summer conditions since the Russo-Japanese War. In one trade post in Okhotsk, the ice disappeared five weeks later than usual. The port of Ola was only cleared of ice on 30 June, whereas it could normally be reached in the first week of June [Ibid. F. 50]. Due to icy conditions, the Baychimo was unable to call at some of the northernmost posts of the Chukotsk Peninsula, like North Cape and Pylgin, on the turf of the Karieff Brothers [Ibid. F. 13]. To make matters worse, the Baychimo sustained heavy damage when it got stuck in shallow waters.

These kind of logistical problems were commonplace in the region: confronted with the unusual summer conditions, Hoogendijk had to admit that the company had started on a "too extensive programme, without sufficient preparation in advance" [Ibid. F. 64]. The logistical problems of other companies added to the chaos. In the summer of 1921, a crew of Japanese fishermen was not retrieved from Kamchatka in time, and so was left without food and suitable clothing for the winter. The crew raided the $\mathrm{HBC}$ post at Khadirka, allegedly murdering five company employees. Before a Japanese warship picked them up, the fishermen also attacked a Russian rescue party. The raid caused considerable damage to the operation, with a loss amounting to $\$ 9,500$ [TNA. BH 1/2702. A 92/28/2. F. 4-5]. In addition, the HBC feared an essential loss of "prestige in the area", and therefore threw all its energy, and its connections with the Foreign Office, into getting the Japanese government to repay the damages. Problems also stemmed from working with chartered vessels. During the 
summer of 1922, HBC agents were confronted with the mutinying crew of the Koyo Maru. Under threat of violence, they were forced to give the sailors a $60 \%$ increase to their pay. The difficulties of organizing the logistics of expansion were not an issue solely confined to Kamchatka. In supplying the Western Arctic, such forms of cooperation also created problems, which is one reason why the $\mathrm{HBC}$ ordered the construction of a new schooner for its Western Arctic operations in Canada.

Next to the logistical problems and the violence, competition was another disturbing factor, in particular from the American firms who had a strong foothold in the area. The Seattle-based fur trader Olaf Swenson, who was already active in Siberia before World War I, operated with some schooners in the area, and also had contractors disturbing the trade in the HBC district of the Kamchatka River [TNA. BH 1/2629. A 92/8/6. F. 9]. In addition to Swenson, two American firms, Wulfsohn \& Co and Seidenverg \& Wittenberg, a Russian company and a Japanese trading business were active in the seas of the Far East [TNA. BH 1/2628. A 92/8/1. F. 24]. There was an intricate link between competition and the ability to procure supplies in the region. A multitude of suppliers undermined the model, as it increased the ability of local traders to source supplies and sell to multiple channels. In 1921, the HBC trade post and small settlement of Tigil could drive prices up due to the activities of Swenson in the area. The following year, the $\mathrm{HBC}$ was unable to call at the post due to fog and coal shortage, which again put Swenson in a strong position. In Bolshetersk, hunters went to sell their furs directly in Petropavlovsk, which drove up prices for sable skins [Ibid. F. 67]. Hoogendijk mentioned the high prices for sable, driven up by competition, as one of the largest risks to future trading operations. The HBC had particularly underestimated the competition from Swenson, whose long-standing interest in the area was bolstered in 1922 by fresh capital. The HBC came to the conclusion that the peninsula was not large enough for both concerns to operate. In the autumn of 1922, contacts were established between the two companies in order to make future arrangements for the exploitation of Kamchatka.

Other than setting the conditions for calling at remote trade posts, nature also influenced levels of competition. The entry of the HBC coalesced with declining yields of sable hunting in the Kamchatka Peninsula, which added to the intensity of competition. Further north in the Chukotsk Peninsula, a particularly harsh winter meant that the natives were preoccupied with saving their reindeer herds rather than hunting white foxes [Ibid. F. 13].

Another fundamental misjudgment was political. The Far East was the scene of various struggles between the Whites and the Reds, the outcomes of which were often hard to follow. For instance, merchants in Anadyr, unable to cope with communist ideas about economic organization, killed the members of the first Soviet Revkom in January 1919: they established their own local governing organ whilst also pretending to form a cooperative to the Kamchatka Revkom [Gray, p. 90]. In August of the same year, however, 
the Soviets reconquered Anadyr, but it did not seem to affect the Karieff Brothers [Nutall, p. 87]. Between 1920 and 1922, the territory in which the company operated was formally under the control of the Far East Republic (FER), a Soviet puppet state designed to act as a buffer between occupied territory and the USSR, which but temporally ended the effort to restore its territorial integrity [Wood, p. 187]. The situation remained however chaotic, with different factions struggling for power. Settlements under revolutionary control, certainly in the remoter parts, were often based on tiny and primitive party cells with little or no central oversight [Cannon, p. 21]. Equally, White warlords could not guarantee ideal trading conditions. Trade reports in 1922 describe the Whites in the Okhotsk area as nothing more than freebooters and the White general as a "brigand". Indeed, the company's expeditions were provided with extra money to bribe local officials.

Despite the grim political and economic prospects, the Dutch leader of the expedition Hoogendijk followed an ambitious course of action. During the summer of 1922, HBC agents on board the supply ships established new posts on the Kamchatka Peninsula, in Ayan, Uka and further north. Again, this all depended upon finding local Russian partners with the right qualifications. For Uka, the HBC hired a trader called Ofshanikoff. Ofshanikoff had been in the service of Tchurin \& Co for twelve years: this was a trading company active in Pacific seal hunting. Given his experience in the fur trade and contacts with the local population, this figure was considered a major future asset: "He has considerable influence among the native population in his district and it is therefore good business and competitors from outside will be handicapped as long as he remains in the service of the company" [TNA. BH 1/2628. A 92/8/1. F. 24]. In addition to the new posts, Hoogendijk also renewed and improved existing agreements during that summer with local traders. This was the case for the most important partner, the Karieff Brothers from Anadyr, whom Hoogendijk tried to tie more closely to the HBC by offering a 10-year exclusivity contract (with an exit penalty of $\$ 25,000)$ [Ibid. F. 20]. The renewed contract also relieved some of the HBC's obligations that were hard to maintain, foremost the provision of some of the northernmost posts.

\section{From expedition to fiasco (1923-1925)}

Not long after the HBC had established a new trade post in the summer of 1922, the Japanese gave up Vladivostok in October. In December 1922, the Far East Republic was incorporated into the USSR, and White control over the Kamchatka coastline finally came to an end. How did the HBC perceive the end of the Civil War in favor of the Soviets? The company was well aware of the state's hostility towards foreign business, but they nonetheless hoped to strike a deal with the Soviets and continue business. Hoogendijk reported that a regime change would probably not alter much in the immediate future, expressing "the hope that a Government monopoly 
of trade will not be declared after arrival of the Company's vessel with fresh supplies next year" [TNA. BH 1/2629. A92/8/1. F. 69].

Indeed, the need for supplies in the area seemed to have been a major incentive for the Soviet government to continue trading in the area. The regime change did not alter the needs of the remote settlements and communities. A few months after the end of the Civil War, Hoogendijk managed to strike a deal with the Soviet authorities, which Moscow ratified on 28 March 1923, for the "joint exploitation" of the fur wealth in Kamchatka and the ChukotskAnadirsk region. In contrast, other trading companies, like Swenson (who operated after 1922 without Hibbard), were less fortunate and saw their possessions confiscated by the Soviet authorities [Swenson, p. 163]. Olaf Swenson was even briefly arrested in Vladivostok. The HBC was allowed to trade furs during the ice-free season of 1923, calling at a series of trade posts along the peninsula. In return, the company promised to ship in supplies to the value of $\$ 350,000$ [TNA. BH 1/2629. A 92/8/3. F. 19]. Profits made on fur sales had to be shared, however, between the HBC and the Commissariat of Foreign Trade (NKVNT). In addition, the local Vneshtorg issued a $10 \%$ tax on the total value of the furs collected. It may seem strange that the company continued operations at this point. However, the joint monopoly on furs was, from a company point of view, perhaps not so undesirable, as competition had been identified as one of the major risks to trade in the area, as had corruption under the White authorities. At least cooperation with the Soviet state now put the HBC in the seemingly comfortable position of monopoly supplier and buyer in the area.

Things turned out differently, however. To begin with, the company agreed to ship in more supplies during the summer of 1923 (worth $\$ 119,478$ in addition to the agreed-upon supplies worth $\$ 350,000$ ) in order to meet the wants of the local population. With this, the company hoped that the Soviet government would recognize its good intentions [TNA. BH 1/2629. A 92/8/4. F. 14]. However, in terms of taxation, things went wrong. According to the agreement, the $\mathrm{HBC}$ would pay $10 \%$ on the selling price, which amounted to $\$ 48,500$. However, the HBC refused to pay, as it was faced with other, unexpected tax claims. A surprise demand for 61,300 gold rubles was made by the customs house in Chita in November 1923. Other customs houses issued similar duties, like the one in Petropavlovsk. The HBC made official complaints to the Commissariat of Foreign Affairs in London, expressing that it "was losing faith in the protection of its legal rights in the territory of Soviet Russia" [TNA. BH 1/2735. A 92/78/1. F. 8]. Still, the company did not intend on giving up. During the winter of 1923-24, preparations were made for another summer shipment, again stressing the well-being of the local population: "the company is willing to continue the large and difficult undertaking already commenced to develop the economic welfare of the inhabitants in the Far East" [Ibid. F. 9].

The joint operation with the Soviet authorities never turned into a workable solution for the HBC. Despite the attractive trade monopoly, the $\mathrm{HBC}$ seriously underestimated the hostile attitude towards foreign 
intruders. In April 1924, local governments further stirred up hostility towards the largest international fur business with a press campaign against the foreign monopoly, and not much later company assets were arrested in Petropavlovsk and other posts. The NKVNT refused to assist the company in its problems with local authorities [TNA. BH 1/2629. A 92/8/7. F. 105]. In a last attempt to save the Kamchatka concession in 1924, the HBC tried to involve ARCOS, the Soviet trade agency in London, in a deal with Vneshtorg so as to provide more security for the HBC's operations. ARCOS, however, refused to assist the HBC: "the board of directors of Arcos, are opposed to undertaking any obligations or responsibilities in this matter, and intimated that they have considerable business... which is conducted with far less trouble" [Ibid. F. 11].

Faced by renewed hostility and legal uncertainties, the HBC telegraphed Anton Hoogendijk in May 1924, urging him to end the Kamchatka expedition as soon as possible. The telegram stated: "in view of constant claims making business utterly impossible have decided not to risk any more money in Kamchatka even though we should lose greatly through this attitude" [TNA. BH 1/2702. A 92/28/2. F. 10]. In July 1924, the HBC's Russian business had come to a complete standstill and the Kamchatka business went into liquidation. The last shadowy prospect of doing business in Siberia was now gone, and the company counted its losses. Contrary to high expectations and despite substantial investments, the Kamchatka adventure resulted in a substantial loss for the HBC. By November 1924, the company had invested the considerable sum of $\$ 735,327.07$ in the stores, infrastructure and supplies of its Kamchatka operation. The HBC's gamble for a fur empire in the Far East had turned out badly.

However, private trading in remote Kamchatka was by no means discontinued entirely. The $\mathrm{HBC}$ had correctly guessed that the Soviet government would continue to need a foreign trading partner in order to provide for local communities. Somewhat surprisingly, it was Olaf Swenson, the HBC's Swedish-American competitor, who negotiated a new deal, re-entering the area in 1925. Swenson's vessels shipped in American merchandise in accordance with Moscow's specifications on a cost-plus basis in exchange for an assigned quota of furs (also on a cost-plus basis). He recalled later in his well-known memoires Northwest of the World that "in spite of the financial ruin, and the months of initial difficulty, I have no complaint to make against the Soviet government" [Swenson, p. 171]. Swenson would continue to operate along the Siberian coast until 1930. Only then did the USSR take over the supply system entirely.

The new fur empire in Russia's Far East was linked to a set of broader issues, foremost business strategies and overarching geopolitical considerations, and thus did not only derive from a naïve understanding of the political risks. At an earlier stage, there was also considerable pressure 
from the British and, to a lesser extent, Canadian political interests in the area that accompanied their military presence, although this connection had disappeared by the time the HBC's presence surged after 1921.

At the beginning of the twentieth century, the HBC had again embraced a strategy of geographical expansion, which started with the extension of trade posts towards the Canadian North: this was done in an attempt to avoid the heavy competition in the fur trade present elsewhere in the country. The Kamchatka expedition was part of such an expansive strategy, complementary to the new trading activities in the Western Arctic. With its new geographical ambitions in Canada and abroad, the HBC again tapped into the old empire-building mission it had once had as a chartered company. In particular, operating in unclaimed (sub)Arctic spaces was predicated on a kind of wishful thinking from the traders and companies, who hoped to gain the liberty of being able to operate without government interference. The HBC jealously observed how American traders operated in the area without much Russian state interference, while also noting how easily they could establish a business monopoly in the high north. The connection between the race to the north in Canada and far eastern expansion is of seminal importance in understanding the risks the company took.

Second, connections across the Bering Strait, those between Alaska and Siberia and Siberia and Canada, were of growing importance from the second half of the nineteenth century. American traders from Nome were virtually the sole supplies of communities in Kamchatka, which they did in exchange for the territory's fur wealth. The exchange of furs for supplies was a central component of the historical fur trade, and had furnished the foundation for trade in the Kamchatka region for decades. Indeed, the HBC had estimated correctly that the need for a (foreign) supplier would not disappear, regardless of the political allegiance of the Kamchatka Peninsula. This primary argument, used extensively by the HBC both internally and externally, also formed the basis for the negotiations between the USSR and the HBC once White control over the area had come to an end. It even offered the prospect of a trade monopoly under Soviet auspices. This assessment proved correct, even though it came with legal uncertainty and it was not the $\mathrm{HBC}$ who ultimately benefited: the American competitor Swenson was granted the right to trade in the area once the HBC had abandoned it.

In the end, the closure of the HBC's trade in the area was largely a political decision. The USSR aimed to control foreign trade in its territory and heavily taxed the operations of the HBC, deliberately or not. The USSR remained largely hostile towards foreign business operating on its soil: but it was perhaps harder to tolerate the HBC, which had been an imperial driving force, in contested territory, than a smaller American trade firm solely devoted to trading in the Far East. However, following from the broader framework of the article, the HBC's failure and heavy losses were not only the result of the struggle between the USSR and the company itself, but also derived from the internal business strategies. On the level of trade competition, the HBC had seriously underestimated 
the historical capacity of American traders to continue operations in Kamchatka in 1921 and 1922. The HBC had underestimated an important last element as well, namely the whims of nature. While supplying remote territories was the company's bread and butter, there are strong indications that the $\mathrm{HBC}$ faced enormous difficulties in providing the area with supplies and monopolizing the fur trade in Kamchatka: doing so seemed to overstretch the abilities of the HBC. As such, a broader perspective reveals that doing business in post-revolutionary Siberia was driven by a number of interlocking rationales, business strategies, geographical connections, demands and supplies that would continue to apply, it was believed, in a radically different political context.

\section{Список литературы}

Black J. L. Great Expectations: Revisiting Canadian Economic Footprints in Siberia, 1890s-1921 // Sibirica : The J. of Siberian Studies. 2013. № 3. P. 1-27.

Bockstoce J. R. White Fox and Icy Seas in the Western Arctic : The Fur Trade, Transportation and Change in the Early Twentieth Century. N. Haven : Yale Univ. Press, 2018. 326 p.

Dalton A. Baychimo: Arctic Ghost Ship. Surrey : Heritage House, 2006. 251 p.

Davenport-Hines R. P. T., Jones G. British Business in Asia since 1860. Cambridge : Cambridge Univ. Press, 2006. 301 p.

Declercq R. Natural Born Merchants : The Hudson Bay Company, Science and Canada's Final Fur Frontiers // Business History. (In print.)

Dunning J., Lundan S. Multinational Enterprises and the Global Economy. Cheltenham : Edward Elgar, 2008. 920 p.

Gray P. The Predicament of Chukotka's Indigenous Movement : Post-Soviet Activism in the Russian Far North. Cambridge : Cambridge Univ. Press, 2005. 245 p.

Hunt W. Alaska : A Bicentennial History. N. Y. : Norton, 1976. 200 p.

McCannon J. Red Arctic : Polar Exploration and the Myth of the North in the Soviet Union, 1932-1939. N. Y. : Oxford Univ. Press, 1998. 234 p.

Murby R. Canada's Siberian Policy 1918-1919: Thesis Master of Arts Slavonic Studies. Vancouver : [S. n.], 1969. 125 p.

Newman P. Merchant Princes. Toronto : Penguin, 1992. 685 p.

Encyclopedia of the Arctic : in 3 Vols. / ed. by M. Nuttal. N. Y. : Routledge, 2004. Vol. 1. 695 p.

Ray A. Periodic Shortages, Native Welfare, and the Hudson's Bay Company 16701930 // The Subarctic Fur Trade : Native Social and Economic Adaptations / ed. by S. Krech. Vancouver : Univ. of British Colombia, 1984. P. 1-21.

Shavit D. The United States in Asia: A Historical Dictionary. N. Y. : Greenwood, 1990. $620 \mathrm{p}$.

Swenson O. Northwest of the World. L. : Hale, 1944. 221 p.

TNA. BH 1/2215. A 12FTMISC/250. F. 2-5; BH 1/2603. A 5/129. F. 223; BH 1/2628. A $92 / 8 / 1$. F. $13,15,20-21,24,33-35,42,44,46,50,64,67$; BH 1/2629. A 92/8/1. F. 69; A $92 / 8 / 3$. F. 19; A 92/8/4. F. 14; A 92/8/6. F. 9; A 92/8/7. F. 11, 105; BH 1/2623. A 92/17/6, F. 78 ; BH 1/2633. A 92/17/21. F. 26; BH 1/2634. A 92/17/25 F. 179-184; BH 1/2702. A 92/28/2. F. 10; A 92/30/1. F. 4-5, 161; BH 1/2735. A 92/78/1. F. 8-9; BH 1/3452. A 93/12. F. 12.

Wood A. Russia's Frozen Frontier : A History of Siberia and the Russian Far East 15811991. L. : Bloomsbury, 2011. 272 p.

Yarzutkina A. Trade on the Icy Coasts: The Management of American Traders in the Settlements of Chukotka Native Inhabitants // Terra Sebus: Acta Musei Sabesiensis. 2014. Special Iss. P. 361-381. 


\section{References}

Black, J. L. (2013). Great Expectations: Revisiting Canadian Economic Footprints in Siberia, 1890s-1921. In The J. of Siberian Studies. No. 3, pp. 1-27.

Bockstoce, J. R. (2018). White Fox and Icy Seas in the Western Arctic: The Fur Trade, Transportation and Change in the Early Twentieth Century. N. Haven, Yale Univ. Press. $326 \mathrm{p}$.

Dalton, A. (2006). Baychimo: Arctic Ghost Ship. Surrey, Heritage House. 251 p.

Davenport-Hines, R. P. T., Jones, G. (2006). British Business in Asia since 1860. Cambridge, Cambridge Univ. Press. 301 p.

Declercq, R (in print). Natural Born Merchants. The Hudson Bay Company, Science and Canada's Final Fur Frontiers. In Business History.

Dunning, J., Lundan, S. (2008). Multinational Enterprises and the Global Economy. Cheltenham, Edward Elgar. 920 p.

Gray, P. (2005). The Predicament of Chukotka's Indigenous Movement: Post-Soviet Activism in the Russian Far North. Cambridge, Cambridge Univ. Press. 245 p.

Hunt, W (1976). Alaska: A Bicentennial History. N. Y., Norton. 200 p.

McCannon, J. (1998). Red Arctic: Polar Exploration and the Myth of the North in the Soviet Union, 1932-1939. N. Y., Oxford Univ. Press. 234 p.

Murby, R. (1969). Canada's Siberian Policy 1918-1919. Thesis Master of Arts Slavonic Studies. Vancouver, S. n. 125 p.

Newman, P. (1992). Merchant Princes. Toronto, Penguin. 685 p.

Nuttal, M. (Ed.). (2004). Encyclopedia of the Arctic. 3 Vols. N. Y., Routledge. Vol. 1. $695 \mathrm{p}$.

Ray, A. (1984). Periodic Shortages, Native Welfare, and the Hudson's Bay Company 1670-1930. In Krech, S. (Ed.). The Subarctic Fur Trade: Native Social and Economic Adaptations. Vancouver, Univ. of British Colombia, pp. 1-21.

Shavit, D. (1990). The United States in Asia: A Historical Dictionary. N. Y., Greenwood. $620 \mathrm{p}$.

Swenson, O (1944). Northwest of the World. L., Hale. 221 p.

TNA. BH 1/2215. A 12FTMISC/250. F. 2-5; BH 1/2603. A 5/129. F. 223; BH 1/2628. A $92 / 8 / 1$. F. 13, 15, 20-21, 24, 33-35, 42, 44, 46, 50, 64, 67; BH 1/2629. A 92/8/1. F. 69; A $92 / 8 / 3$. F. 19; A 92/8/4. F. 14; A 92/8/6. F. 9; A 92/8/7. F. 11, 105; BH 1/2623. A 92/17/6, F. 78; BH 1/2633. A 92/17/21. F. 26; BH 1/2634. A 92/17/25 F. 179-184; BH 1/2702. A 92/28/2. F. 10; A 92/30/1. F. 4-5, 161; BH 1/2735. A 92/78/1. F. 8-9; BH 1/3452. A 93/12. F. 12.

Wood, A. (2011). Russia's Frozen Frontier: A History of Siberia and the Russian Far East 1581-1991. London, Bloomsbury. 272 p.

Yarzutkina, A. (2014). Trade on the Icy Coasts: The Management of American Traders in the Settlements of Chukotka Native Inhabitants. In Terra Sebus: Acta Musei Sabesiensis. Special Iss., pp. 361-381.

The article was submitted on 21.12.2018 